\title{
Spatial distribution of heavy metal contaminations in Yowie Bay sediments and their environmental impacts
}

\author{
Y. M. Alyazichi ${ }^{1,2}$, B. G. Jones ${ }^{1}$ \& E. McLean ${ }^{1}$ \\ ${ }^{I}$ School of Earth and Environmental Sciences, \\ Wollongong University, Australia \\ ${ }^{2}$ Dams and Water Resources Research Centre, \\ Mosul University, Iraq
}

\begin{abstract}
We investigated the distribution of heavy metals $\mathrm{Ni}, \mathrm{Cu}, \mathrm{Zn}, \mathrm{As}, \mathrm{Cd}$ and $\mathrm{Pb}$ in marine sediments in order to evaluate the pollution status in Yowie Bay, in the Port Hacking Estuary, NSW, Australia. Twenty one surface sediments were collected in this study and hydrodynamic parameters (current track and velocity) were also measured in order to explain the distribution of the heavy metals in the bay. Effect Range Low and Effect Range Median statistics were used to assess the environmental effect in order to offer measures to protect the ecosystem from pollution by the accumulation of heavy metals in the bay. The results showed that the heavy metals $\mathrm{Ni}, \mathrm{Cu}, \mathrm{Zn}, \mathrm{As}, \mathrm{Cd}$ and $\mathrm{Pb}$ had similar distribution patterns in surface sediments. The surface sediments were considerably contaminated by copper, cadmium and lead. The highest concentrations of the metals were found to be in the northeast of the bay, which is in close proximity to discharge points and moored watercraft, with the highest reading (sample YO8) having concentrations of $20,107.4,304.2,15,12.3$ and $176.5 \mathrm{ppm}$, respectively. The heavy metal pollution was concentrated in the inner bay, which has greater depth and contains organic matter and muddy particles (illite, kaolinite and chlorite). The sources of pollution by heavy metals were found to be discharge points and human activities (gasoline fumes, watercraft and boatyards) and this pollution began with European settlement which now surrounds the bay.

Keywords: Yowie Bay, sediments, heavy metals, contamination, hydrodynamic, statistical techniques.
\end{abstract}




\section{Introduction}

Heavy metals in marine sediments are originated from both natural processes such as soil erosion and atmospheric inputs, and anthropogenic activity. Heavy metals in ecosystems causes serious environmental problems around the world because of the toxicity, non-biodegradable properties, and resistant and accumulation behaviors of heavy metals [1]. Because of rapid urbanization and industrialization around marine coastal ecosystems, concentrations of heavy metals have increased and heavy metals are being discharged into environmentally sensitive estuaries and bays around the world [2].

Once heavy metals are present in the aquatic environment, they can accumulate in the fine sediment particles via physical, chemical and biological processes $[3,4]$. In addition, ebb tidal currents have the capability to transport fine and very fine particles within the estuary, distributing the chemical pollution away from the discharge source. Tide data are considered useful information for both civil and hydraulic engineers who provide hydraulic descriptions, information for water quality model management and frameworks for evaluating sediment and chemical dynamics in bays [5-7]. Furthermore, heavy metals can be released again into the water column from sediments as free ions, and/or complex compounds when environmental conditions are changed [8]. These heavy metals can have deleterious effects on fauna, flora and aquatic micro-organisms, and can enter into human bodies via the food chain, inhalation or dermal absorption, potentially leading to critical health disorders that affect the nervous system, endocrine system and/or the immune system $[2,9,10]$.

The major objective of this study was to investigate the spatial distribution and toxicology of heavy metals in the marine sediments of Yowie Bay, and their relationship with sediment fractions. The study also evaluates the effect of current and tidal hydrodynamics on the concentration and dispersal of heavy metal pollutants within a typical estuarine bay system.

\section{Experiments}

\subsection{Study area}

Yowie Bay, which is located $30 \mathrm{~km}$ south of Sydney Harbour, is one of several bays belonging to the Port Hacking estuary (Fig. 1). Overall, the inner area of the bay has deeper depths $(>7 \mathrm{~m})$, and the foreshores have been substantially modified [11]. Yowie Bay provides a significant environmental shelter and habitat for flora and fauna, breeding and nursery habitats for several species, and is of economic and social value (e.g. tourism, business enterprises, fisheries and aquaculture). The main freshwater discharge points for the catchment areas are shown in Fig. 1, which shows catchment model segments for Yowie Bay and the adjacent Gymea Bay in yellow. These were determined by Sydney Water (the statutory authority responsible for water supply and management across Sydney). The catchment areas of Yowie Bay are urbanized with a population of approximately 40,240 in the local government area. The sources of contamination are mainly from the 
catchment areas (1658 ha; Fig. 1), and from recreational activities along the coastline such as watercraft, boat yards and fishing, which can in turn affect the water quality of the bay.
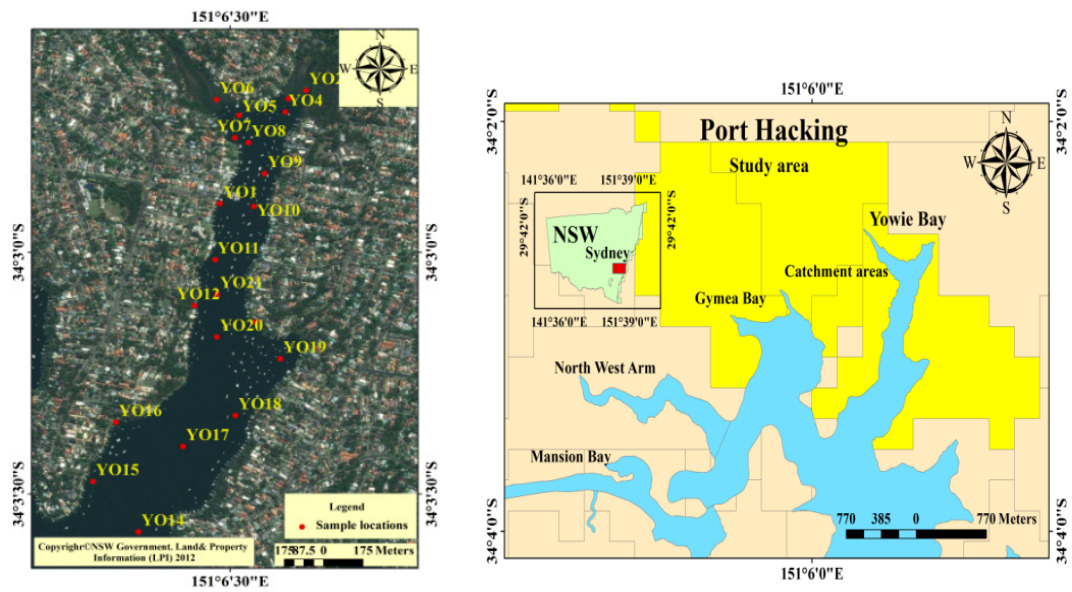

Figure 1: Catchment area and surface sediment sample locations for Yowie Bay, off Port Hacking, NSW, Australia.

\subsection{Sample collections and preparations}

During the summer of 2012, a total of 21 surface sediment samples were collected using a grab sampler by boat (Fig. 1). The sediment samples were reserved for analysis. At each site the water depth and location were recorded using sonar and a Global Positioning System (GPS) respectively. Grain size measurements were performed for all sediment samples using a Malvern Mastersizer 2000. Further analyses were used to obtain the details of the source of sediments, distribution of grain size (sand, silt and clay), and to interpret geochemical results. Heavy metals were measured by X-ray fluorescence spectrometer with a SPECTRO-analytical instrument (XEPOS), following [12] procedure. Hierarchical cluster analysis [13] was applied to distinguish characteristics of the samples. This statistical analysis was achieved using JMP software to include all variables.

Arc GIS desktop software was used to plot the sample sites within the study areas, and to provide advanced geostatistical analysis to create maps. The Kriging method of geostatistical analysis was used [14].

\subsection{Hydrodynamic measurements}

Hydrodynamic conditions including currents and tides in the study area were measured by drogues (Fig. 2). Three drogues were modified from a previous design to permit deployment in estuarine water. These were constructed in the workshop at the University of Wollongong. The height of each drogue was $70 \mathrm{~cm}$, and each drogue consisted of a buoy (ball), with a waterproof enclosure to hold a 
small GPS and a flashing light. A software program was used to plot the movement directions of the drogues and data from each site measured, and the data was uploaded onto Google earth and KMZ files. Data from the GPS has been smoothed to gain an estimate of average velocities over the drogue track.

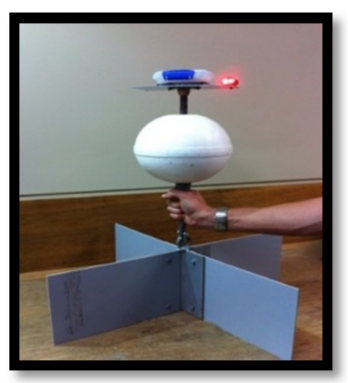

Figure 2: Modified design of the drogue to measure tides and currents.

\section{Results and discussion}

\subsection{Hydrodynamic measurements}

Three drogues were deployed at each site in Yowie Bay at about the same time of day (with a difference of only a few minutes between deployments of each drogue). The drogues were deployed just after high tide in order to capture typical ebb-tidal flow patterns and velocities for the larger tides associated with spring tidal ranges. The drogues were deployed at discharge points and stormwater outlets (numbers 1 and 2) for the catchment areas, and in the middle of the bay (Fig. 3).

The drogue in the middle of the bay (number 3) had a faster speed compared with the other drogues (1 and 2) because of increased current velocities due to a larger tidal storage above these locations. Field methodology was designed so that the current track and velocity data would be compatible with both a descriptive explanation of spatial distribution of sediments and pollutants movement and the data needs of any future hydrodynamic modelling. For this paper only descriptive measures are used to assess the main trajectory of currents and pollutants. Current speeds in the bay had enough capability to transport the fine and very fine particles, including heavy metals, from the edges, shoreline and catchment areas via discharge points, and then to gradually deposit them in deeper areas [15]. This fact accords with the observations in previous research from other areas $[15,16]$.

Hydrodynamic circulation in Yowie Bay is controlled by several factors such as catchment area flows, entry points, wind effects (speed and directions) and tidal velocities. These results correspond with previous studies in different places conducted by $[17,18]$. Wind waves are influential in the resuspension and carriage of fine particles along shallow estuarine margins. Main discharge points carry materials from catchment areas, which are pushed into the bays. The sediment 

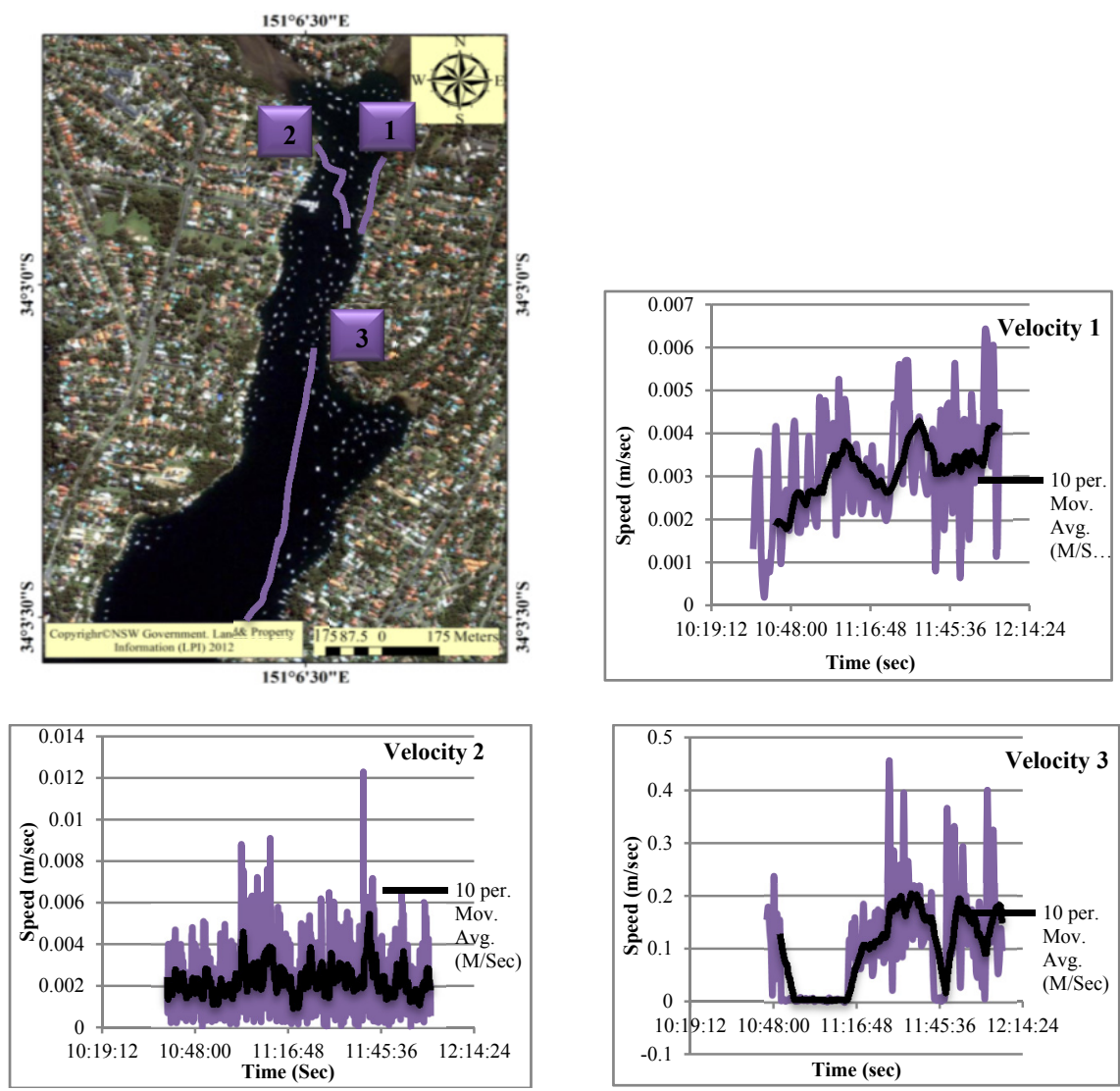

Figure 3: Current track velocities for three drogues in Yowie Bay.

pathway into the bay is in the form of a jet since water velocity decreases gradually when entering the bay, causing deposition of coarse materials close to discharge points and then fine particles further into the bay [19, 20]. Local waves, generated by wind, become more influential in the shallow waters close to the discharge points, leading to resuspension and transport of fine particles into deeper sites, where the current and waves become less active and cannot disturb the bottom sediments. The currents have complex circulations in shallower water, and winddriven current can cause subsequent return flows around the edges of the bay. The fine sediment particles and heavy metals are transported by current and tidal activity and then gradually settle-out at deeper sites in the central part of the bay.

\subsection{Sediments and water depth distribution}

Sediment grain size and water depth varied within the bay. As illustrated in Fig. 4a, a high percentage of sand was found to be located at the shoreline and edge of the bay, which has a shallow water depth $(<2 \mathrm{~m}$, Fig. 4b). The waves and residual currents at these sites are highly active and can disturb the fine 
particles, which may transport them into deeper areas (inner bay). However, muddy (silt and clay) percentages are dominant within the inner and north-east areas of the bay (Fig. 4c), where the water depth is deep and ranges between $5 \mathrm{~m}$ and $20 \mathrm{~m}$ and the waves have slightly lower effects on the bottom sediments. Therefore, fine and very fine particles can settle and accumulate within the inner bay.
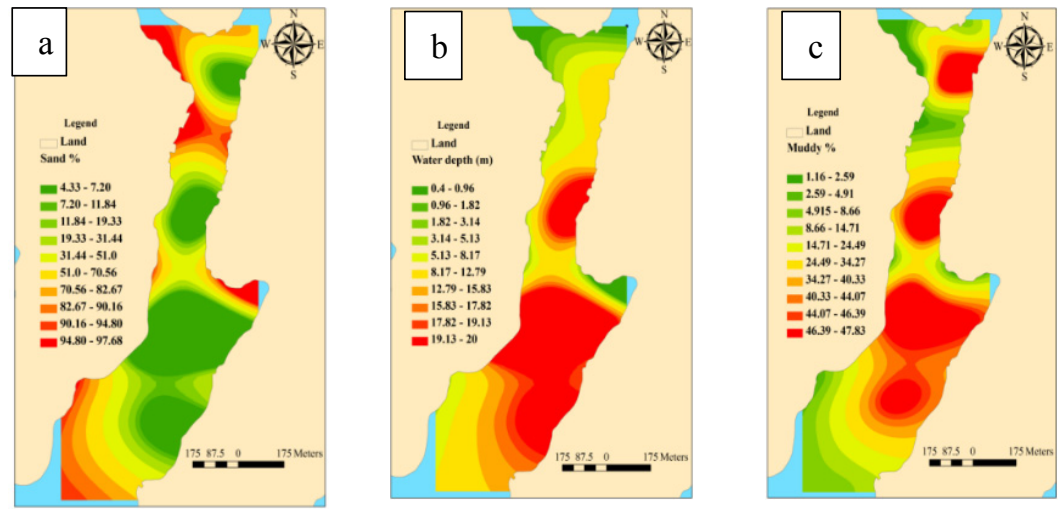

Figure 4: Spatial distribution of: a. sand percentages; b. water depth (m); and c. muddy percentages in Yowie Bay.

\subsection{Spatial distribution of heavy metal pollution}

Heavy metals are analyzed in this study and the minimum, maximum and mean values are presented in Table 1. Prediction maps of heavy metals $\mathrm{Ni}, \mathrm{Cu}, \mathrm{Zn}, \mathrm{As}$, $\mathrm{Cd}$ and $\mathrm{Pb}$ are shown in Fig. 5. The concentration of these metals generally exhibited similar spatial distribution patterns. On the one hand, the highest concentrations of these metals are located in the north and north-west of the bay, because they are close to the discharge points and stormwater outlets from catchment areas. Notably, the concentration of heavy metals also increased around boat moorings and boatyards. Heavy metals were also concentrated within the inner bay which was dominated by muddy particles (silt and clay) and organic

Table 1: Basic statistics of metals with ERL (effect range low) and ERM (effect range median) values in ppm.

\begin{tabular}{|c|c|c|c|c|c|c|}
\hline Heavy metals & $\mathrm{Ni}$ & $\mathrm{Cu}$ & $\mathrm{Zn}$ & $\mathrm{As}$ & $\mathrm{Cd}$ & $\mathrm{Pb}$ \\
\hline Minimum & 1.7 & 4.5 & 15.2 & 1.6 & 5.5 & 6.3 \\
\hline Maximum & 20 & 107.4 & 304.2 & 17 & 12.3 & 176.5 \\
\hline Mean \pm SD & $10 \pm 6.5$ & $35.2 \pm 29$ & $110 \pm 87$ & $7.7 \pm 4.4$ & $9 \pm 2.1$ & $65.4 \pm 53$ \\
\hline ERL & $20.9(6)$ & 34 & $150(36)$ & $8.2(34)$ & $\begin{array}{c}1.2 \\
(21)\end{array}$ & $46.7(39)$ \\
\hline ERM & $51.6(-)$ & $\begin{array}{c}270 \\
(-)\end{array}$ & $\begin{array}{c}410 \\
(-)\end{array}$ & $\begin{array}{c}70 \\
(-)\end{array}$ & $\begin{array}{c}9.6 \\
(7)\end{array}$ & $\begin{array}{c}218 \\
(-)\end{array}$ \\
\hline
\end{tabular}

Values enclosed in parentheses are the numbers of samples are excessed ERL and ERM. 

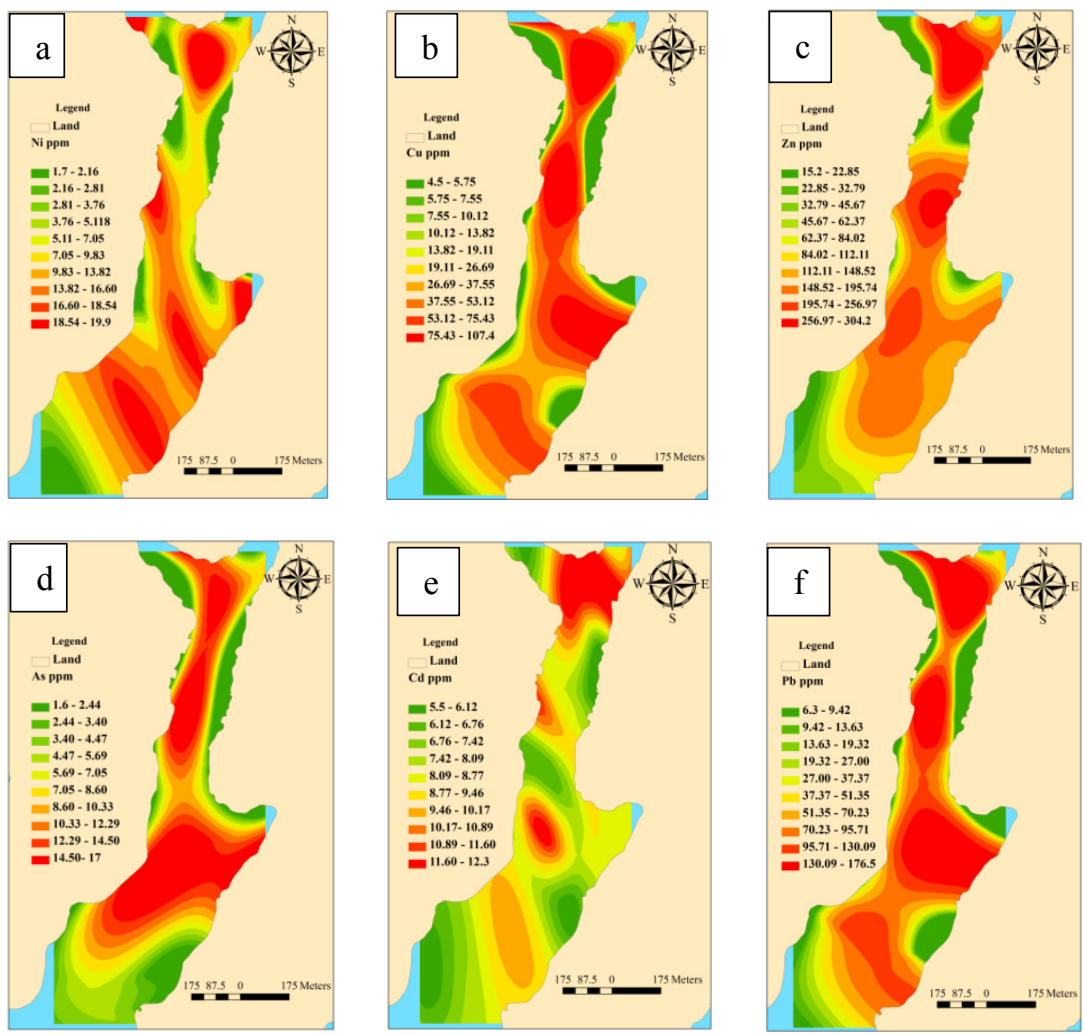

Figure 5: Spatial distribution of heavy metals: a. Ni; b. Cu; c. Zn; d. As; e. Cd; and $\mathrm{f}$. $\mathrm{Pb}$ in sediments in Yowie Bay.

matter that can absorb and accumulate heavy metals in clay minerals at these sites. The concentration of heavy metals decreases toward the edges and shoreline of the bay for two reasons. First, the edges of the bay are dominated by the sand fractions. Second, the currents and waves become more active at the edges and can disturb fine particles, which are then transported and gradually deposited in deeper areas. Furthermore, the level of these metals varied in the inner part of the bay, based on mobility of each metal, sediment types and environmental conditions. On the other hand, the variation of these metals at the edges and mouth of the bay was found to be relatively small. Heavy metal levels in this study are compared with harmful biological effect values, which comprise the effect range low (ERL) and effect range median (ERM) in estuarine and marine sediments suggested by U.S. National Oceanic and Atmospheric Administration (NOAA) [21]. The concentrations of these metals in Yowie Bay were less than ERM values. Also, the concentrations of heavy metals $\mathrm{Ni}, \mathrm{Zn}$ and As were less than ERL values, which show low pollution within bay's sediments. The concentration of heavy metals $\mathrm{Cu}$ and $\mathrm{Pb}$ that were above the ERL value, which were considered to be moderate pollution for Yowie Bay, were found in the northern, north-western and 
inner parts of the bay, as shown in Fig. 5. This concentration is a result of discharge points, as well as gasoline fumes from cars and boats.

\subsection{Statistical techniques}

Fig. 6 and Table 2 demonstrate the results of hierarchical cluster analysis (HCA). Three clusters of variables can be recognized from these statistics. Based on similar characteristics, sediment fractions and heavy metals can be classified. Cluster A (red) contains samples from deep water and has low percentages of sand, high percentages of mud (silt and clay), and the highest concentration of heavy metals. Samples in this cluster, which are located close to discharge points in the inner bay and around sites that have watercrafts (Fig. 6), reflect anoxic condition. These sites may have high percentages of organic matter and clay minerals, which can be a trap for heavy metals, according to Ligero et al. [21]. Cluster B (green) samples have higher percentages of sand lower percentages of mud, and lower levels of heavy metals than cluster A.

In contrast, cluster $\mathrm{C}$ (blue) consists of samples from shallow water, with the highest percentages of sand, lowest percentages of mud, and lowest concentration of heavy metals. These samples are located at the edges of the bay and in sites that have lower concentrations of pollutants in the bay, and indicate an oxic condition. The concentration patterns of $\mathrm{Ni}, \mathrm{Cu}, \mathrm{Zn}, \mathrm{As}, \mathrm{Cd}$ and $\mathrm{Pb}$ in surface sediments in Yowie Bay suggest that the sources of pollution had emerged from the catchment area, which includes residential, industrial, roadsides, as well as boatyards and watercraft. The presence of these heavy metals has deleterious environmental effects on both local fauna and flora. Heavy metals can enter humans via the food chain or by inhalation or dermal absorption, and this may lead to critical health disorders that affect the nervous system, endocrine system and/or the immune system [9, 10].

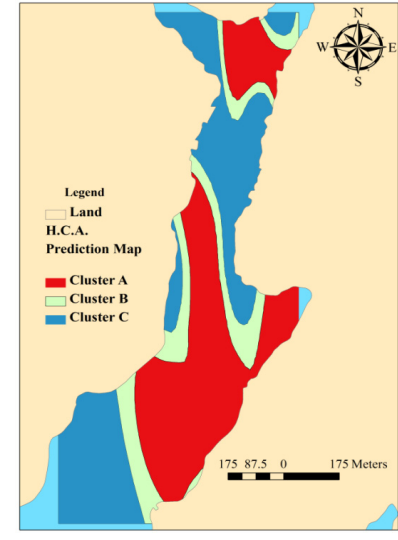

Figure 6: Cluster analysis of variables and environmental depositions.
Table 2: Percentages and concentrations of variables in three clusters based on HCA.

\begin{tabular}{|l|l|l|l|}
\hline Variables & $\begin{array}{c}\text { Cluster } \\
\text { A }\end{array}$ & $\begin{array}{c}\text { Cluster } \\
\text { B }\end{array}$ & $\begin{array}{l}\text { Cluster } \\
\text { C }\end{array}$ \\
\hline Depth $(\mathrm{m})$ & 16.53 & 3.30 & 4.81 \\
\hline Sand\% & 9.83 & 49.47 & 85.84 \\
\hline Silt\% & 76.40 & 42.99 & 11.93 \\
\hline Clay\% & 13.78 & 7.54 & 2.22 \\
\hline $\mathrm{Ni}$ & 17.40 & 12.33 & 4.48 \\
\hline $\mathrm{Cu}$ & 64.54 & 53.47 & 11.62 \\
\hline $\mathrm{Zn}$ & 198.54 & 172.57 & 36.11 \\
\hline $\mathrm{As}$ & 12.69 & 8.27 & 4.29 \\
\hline $\mathrm{Cd}$ & 9.00 & 11.33 & 7.95 \\
\hline $\mathrm{Pb}$ & 113.46 & 109.40 & 22.73 \\
\hline
\end{tabular}




\subsection{Comparisons with other areas}

The heavy metal concentrations that were measured in Yowie Bay were compared with the concentrations of heavy metals from marine sediments in previous Australian studies [23, 24] and around the world [25, 26]. The Huon estuary is essentially a non-industrialized zone and might contain a low level of potentially toxic heavy metals. In contrast, the Port Jackson estuary, Tyne estuary and Avilés estuary have high concentrations of heavy metals and would be expected to contain toxic metals due to the large amounts of waste, including solid and liquid, organic and inorganic, discharged into these bays from residential and industrial areas as well as boat yards and watercraft [23, 26, 27].

In addition, limited treatment of waste in these bays also leads to higher concentrations of toxic metals. As Table 3 illustrates, the sediments in Yowie Bay are polluted with heavy metals such as $\mathrm{Cu}, \mathrm{Zn}$ and $\mathrm{Pb}$, while the sediments in the Huon estuary have fewer pollutants than the sediments in the Port Jackson estuary, Tyne estuary and Avilés estuary.

The main anthropogenic pollution sources of heavy metals in the samples of the study area can be attributed to discharge points and stormwater drains from roadways and residential areas, as well as the number of marine services and the large numbers of moored watercraft. Yowie Bay, which is deemed to be a partlysheltered environment exposed to the open sea and to high winds from the north and north-west, provides a useful example of the distribution of pollutant concentrations by current and wave activity. As a consequence, the heavy metals are gradually precipitated within deeper sites to the inner and west of the Bay (Fig. 6).

Table 3: Comparison of heavy metals (ppm) from the study area with other estuaries in Australia and the worldwide.

\begin{tabular}{|l|c|c|c|c|c|c|c|}
\hline \multicolumn{1}{|c|}{ Location } & Country & $\mathrm{Ni}$ & $\mathrm{Cu}$ & $\mathrm{Zn}$ & $\mathrm{As}$ & $\mathrm{Cd}$ & $\mathrm{Pb}$ \\
\hline $\begin{array}{l}\text { Huon [24] } \\
\begin{array}{l}\text { Range } \\
\text { Mean }\end{array}\end{array}$ & Australia & $\begin{array}{c}2-28 \\
20\end{array}$ & $\begin{array}{c}7-32 \\
17\end{array}$ & $\begin{array}{c}2-66 \\
40\end{array}$ & $\begin{array}{c}4-25 \\
16\end{array}$ & $\begin{array}{c}<10 \\
<10\end{array}$ & $\begin{array}{c}2-48 \\
25\end{array}$ \\
\hline $\begin{array}{l}\text { Port Jackson [27] } \\
\text { Range } \\
\text { Mean }\end{array}$ & Australia & $\begin{array}{c}5-24 \\
22\end{array}$ & $\begin{array}{c}9-1053 \\
188\end{array}$ & $\begin{array}{c}108-7622 \\
651\end{array}$ & $\mathrm{BDL}$ & $\begin{array}{c}\mathrm{BDL}-24 \\
0.8\end{array}$ & $\begin{array}{c}38-3604 \\
364\end{array}$ \\
\hline $\begin{array}{l}\text { Tyne Estuary [25] } \\
\text { Mean }\end{array}$ & $\mathrm{UK}$ & 34 & 92 & 421 & $\mathrm{NA}$ & 2.2 & 187 \\
\hline $\begin{array}{l}\text { Avilés Estuary [26] } \\
\text { Mean }\end{array}$ & Spain & 6.9 & 34.9 & 1437.2 & 18.8 & 5.9 & 176.06 \\
\hline $\begin{array}{l}\text { Yowie Bay (this study) } \\
\text { Range } \\
\text { Mean } \pm \text { SD }\end{array}$ & Australia & $\begin{array}{c}2-20 \\
10 \pm 7\end{array}$ & $\begin{array}{c}5-107 \\
35 \pm 3\end{array}$ & $\begin{array}{c}15-304 \\
110 \pm 9\end{array}$ & $\begin{array}{c}2-17 \\
8 \pm 4\end{array}$ & $\begin{array}{c}6-12 \\
9 \pm 2\end{array}$ & $\begin{array}{c}6-117 \\
65 \pm 5\end{array}$ \\
\hline
\end{tabular}

BDL is below detection limit and NA is not available.

\section{Conclusions}

To evaluate the environmental status of Yowie Bay in NSW, Australia, and to identify potential sources of pollution of marine sediments, heavy metals were 
analyzed in surface sediments. The heavy metals of interest were $\mathrm{Ni}, \mathrm{Cu}, \mathrm{Zn}, \mathrm{As}$, $\mathrm{Cd}$ and $\mathrm{Pb}$. Track current velocities of ebb tides were measured to determine pollutant pathways under tidal flows. Hierarchical cluster analysis (HCA) was applied, and the mean concentrations of heavy metals were compared with deleterious biological effect values. The results indicate that the bay has low contamination of $\mathrm{Ni}, \mathrm{Zn}$ and $\mathrm{As}$, whereas there is moderate to considerable contamination from $\mathrm{Cu}, \mathrm{Cd}$ and $\mathrm{Pb}$. Statistical analysis of sediment samples recognized three clusters of environments. The first and second cluster represent moderately to considerably polluted environments. The third cluster shows unpolluted environments. Stormwater outlets and discharge points, as well as watercraft and boatyards, are considered to be the sources of heavy metals in Yowie Bay, together with emissions such as gasoline fumes from vehicle and boat exhausts which have accumulated over time since European settlement. In further studies, there is a need to analyze water and organisms to determine acceptable levels of heavy metals in order to protect aquatic organisms from heavy metal pollution. Physical, chemical and biological treatment methods are recommended to remove and/or reduce contamination from stormwater outlets before discharge into the bay.

\section{Acknowledgements}

This paper is a part of the first author's $\mathrm{PhD}$ thesis undertaken at the School of Earth and Environmental Sciences, University of Wollongong. It was financially supported by the Ministry of Higher Education and Scientific Research, Iraqi and GeoQuEST Research Centre, University of Wollongong, Australia.

\section{References}

[1] Wei, C., Wang, C., \& Yang, L., 2009. Characterizing spatial distribution and sources of heavy metals in the soils from mining-smelting activities in Shuikoushan, Hunan Province, China. Journal of Environmental Sciences, 21, 1230-1236.

[2] Alyazichi, Y. M., Jones, B. G., \& McLean, E., 2014. Environmental Assessment of Benthic Foraminiferal and Pollution in Gunnamatta Bay in NSW, Australia. Conference Proceedings of 8th Asian Rock Mechanics International Symposium Sapporo, Japan. 14-16 October.

[3] Alyazichi, Y. M., Jones, B. G., \& McLean, E., 2015. Spatial and temporal distribution and pollution assessment of trace metals in marine sediments in Oyster Bay, NSW, Australia. Bulletin of Environmental Contamination and Toxicology, 94, 52-57.

[4] Yuan, H., Song, J., Li, X., Li, N., \& Duan, L., 2012. Distribution and contamination of heavy metals in surface sediments of the South Yellow Sea. Marine Pollution Bulletin, 64, 2151-2159.

[5] Hinwood, J. B., McLean, E. J., Carev, J., \& Greilach, P., 2001. Use of a water quality model in management of a small estuary, coasts and ports. 
Conference Proceedings of Coasts \& Ports 2001, September 2001, Surfers Paradise, pp 330-337.

[6] McLean, E. J., \& Hinwood, J. B., 2007. Appraisal of a one-dimensional model, field data and dimensionless parameters in a study of estuarine circulation. Coasts \& Ports 2007, September 2007, Melbourne, Paper 76, $1-7$.

[7] Maanen, B., Coco, G., Bryan, K. R., \& Friedrichs, C., 2013. Modeling the morphodynamic response of tidal embayments to sea-level rise. Ocean Dynamics, 63, 1249-1262.

[8] Hamzeh, M., Ouddane, B., Daye, M., \& Halwani, J., 2014. Trace Metal Mobilization from Surficial Sediments of the Seine River Estuary. Water, Air, and Soil Pollution, 225, 1-15.

[9] Romero, A., González, I., Fernández, I. M., \& Galán, E., 2013. Evaluation of trace element contamination changes in soils using a new normalization factor: Application to the Guadiamar soils (SW Spain) affected by a mine spill in 1998. Journal of Geochemical Exploration, 124, 29-39.

[10] Zhao, L., Xu, Y., Hou, H., Shangguan, Y., \& Li, F., 2014. Source identification and health risk assessment of metals in urban soils around the Tanggu chemical industrial district, Tianjin, China. Science of the Total Environment, 468-469, 654-662.

[11] Albani, A. D., \& Cotis, G., 2004. Port Hacking past and present Sutherland: Sutherland Shire Council, Sutherland.

[12] Norrish, K., \& Chappell, B., 1977. X-ray Fluorescence Spectrometry. In: Zussman, J. (ed.) Physical Methods in Determinative Mineralogy. Academic Press London. 201-272.

[13] Zhang, W., Zhao, D., \& Wang, X., 2013. Agglomerative clustering via maximum incremental path integral. Pattern Recognition, 46, 3056-3065.

[14] Li, J., \& Heap, A. D., 2008. A Review of Spatial Interpolation Methods for Environmental Scientists. Geoscience Australia, 137pp.

[15] Gong, W., Jia, L., Shen, J., \& Liu, J. T., 2014. Sediment transport in response to changes in river discharge and tidal mixing in a funnel-shaped micro-tidal estuary. Continental Shelf Research, 76, 89-107.

[16] Mantovanelli, A., Marone, E., da Silva, E. T., Lautert, L. F., Klingenfuss, M. S., Prata, V. P., Noernberg, M. A., Knoppers, B. A., \& Angulo, R. J., 2004. Combined tidal velocity and duration asymmetries as a determinant of water transport and residual flow in Paranaguá Bay estuary. Estuarine, Coastal and Shelf Science, 59, 523-537.

[17] McLean, E. J., \& Hinwood, J. B., 2000. Modelling entrance resistance in estuaries. Conference Proceedings of 27th International Conference on Coastal Engineering, Sydney, New South Wales, Australia. 3446-3457.

[18] McLean, E.J., Hinwood, J. B. \& McPherson, B. L. 2003: "Simplified Science: the DST for Lake Conjola entrance management." Coasts \& Ports, Sept. 2003, Auckland, paper 90, 8 pp.

[19] Fujiwara, T., Nakata, H., \& Nakatsuji, K., 1994. Tidal-jet and vortex driving of the residual circulation in a tidal estuary. Continental Shelf Research, 14, 1025-1038. 
[20] Lee, S. B., Birch, G. F., \& Lemckert, C. J., 2011. Field and modelling investigations of fresh-water plume behaviour in response to infrequent high-precipitation events, Sydney estuary, Australia. Estuarine, Coastal and Shelf Science, 92, 389-402.

[21] Ligero, R. A., Barrera, M., Casas-Ruiz, M., Sales, D., \& López-Aguayo, F., 2002. Dating of marine sediments and time evolution of heavy metal concentrations in the Bay of Cádiz, Spain. Environmental Pollution, 118, $97-108$.

[22] Fernandes, L., Nayak, G. N., Ilangovan, D., \& Borole, D. V., 2011. Accumulation of sediment, organic matter and trace metals with space and time, in a creek along Mumbai coast, India. Estuarine, Coastal and Shelf Science, 91, 388-399.

[23] Birch, G. F., \& Taylor, S. E., 1999. Source of heavy metals in sediments of the Port Jackson estuary, Australia. Science of The Total Environment, 227, 123-138.

[24] Jones, B. G., Killian, H. E., Chenhall, B. E., \& Sloss, C. R., 2003. Anthropogenic effects in a coastal lagoon: geochemical characterization of Burrill Lake, NSW, Australia. Journal of Coastal Research, 19, 621-632.

[25] Bryan, G. W., \& Langston, W. J., 1992. Bioavailability, accumulation and effects of heavy metals in sediments with special reference to United Kingdom estuaries: a review. Environmental Pollution, 76, 89-131.

[26] Sierra, C., Boado, C., Saavedra, A., Ordóñez, C., \& Gallego, J. R., 2014. Origin, patterns and anthropogenic accumulation of potentially toxic elements (PTEs) in surface sediments of the Avilés estuary (Asturias, northern Spain). Marine Pollution Bulletin, 86, 530-538.

[27] Irvine, I., \& Birch, G. F., 1998. Distribution of heavy metals in surficial sediments of Port Jackson, Sydney, New South Wales. Australian Journal of Earth Sciences, 45, 297-304. 